\title{
Yield QTL analysis of Oryza sativa x O. glumaepatula introgression lines
}

\author{
Priscila Nascimento Rangel(1), Rosana Pereira Vianello(1), Arthur Tavares Oliveira Melo(1), \\ Paulo Hideo Nakano Rangel ${ }^{(1)}$, João Antônio Mendonça ${ }^{(1)}$ and Claudio Brondani ${ }^{(1)}$
}

(1)Embrapa Arroz e Feijão, Rodovia GO-462, Km 12, CEP 75375-000 Santo Antônio de Goiás, Goiás, Brazil. E-mail: pn.rangel@gmail.com,
rosana.vianello@embrapa.br, arthurmelobio@gmail.com, paulo.hideo@embrapa.br, joao.mendonca@embrapa.br, claudio.brondani@embrapa.br

Abstract - The objective of this work was to evaluate the yield performance of two generations $\left(\mathrm{BC}_{2} \mathrm{~F}_{2}\right.$ and $\mathrm{BC}_{2} \mathrm{~F}_{9}$ ) of introgression lines developed from the interspecific cross between Oryza sativa and O. glumaepatula, and to identify the SSR markers associated to yield. The wild accession RS-16 (O. glumaepatula) was used as donor parent in the backcross with the high yielding cultivar Cica-8 (O. sativa). A set of $114 \mathrm{BC}_{2} \mathrm{~F}_{1}$ introgression lines was genotyped with 141 polymorphic SSR loci distributed across the whole rice genome. Molecular analysis showed that in average $22 \%$ of the $O$. glumaepatula genome was introgressed into $\mathrm{BC}_{2} \mathrm{~F}_{1}$ generation. Nine $\mathrm{BC}_{2} \mathrm{~F}_{9}$ introgression lines had a significantly higher yield than the genitor Cica- 8 , thus showing a positive genome interaction among cultivated rice and the wild O. glumaepatula. Seven QTL were identified in the overall $\mathrm{BC}_{2} \mathrm{~F}_{2}$, with one marker interval (4879-EST20) of great effect on yield. The alleles with positive effect on yield came from the cultivated parent Cica-8.

Index terms: AB-QTL, breeding, genetic pool, molecular markers, target genome region, yield performance.

\section{Análise de QTL da produtividade em linhagens de introgressão de Oryza sativa x O. glumaepatula}

Resumo - $\mathrm{O}$ objetivo deste trabalho foi avaliar o desempenho produtivo de duas gerações $\left(\mathrm{RC}_{2} \mathrm{~F}_{2}\right.$ e $\left.\mathrm{RC}_{2} \mathrm{~F}_{9}\right)$ de linhagens de introgressão, desenvolvidas a partir do cruzamento interespecífico entre Oryza sativa e $O$. glumaepatula, bem como identificar marcadores SSR associados à produtividade. O acesso selvagem RS-16 (O. glumaepatula) foi utilizado como doador parental no retrocruzamento com a cultivar elite Cica-8 (O. sativa). Uma série de 114 linhagens de introgressão $\mathrm{RC}_{2} \mathrm{~F}_{1}$ foi genotipada com 141 locos SSR polimórficos distribuídos ao longo de todo o genoma do arroz. A análise molecular indicou que, em média, 22\% do genoma de O. glumaepatula foi introgredida na geração $\mathrm{RC}_{2} \mathrm{~F}_{1}$. Nove linhagens de introgressão $\mathrm{RC}_{2} \mathrm{~F}_{9}$ tiveram produção significativamente maior que o genitor Cica-8, o que mostra uma interação genômica positiva entre o arroz cultivado e a espécie silvestre O. glumaepatula. Sete QTL foram identificados em toda geração $\mathrm{RC}_{2} \mathrm{~F}_{2}$, com um intervalo de marcadores (4879-EST20) de grande efeito sobre a produtividade. Os alelos com efeitos positivos sobre a produtividade foram provenientes do genitor cultivado Cica-8.

Termos para indexação: AB-QTL, melhoramento, base genética, marcadores moleculares, região-alvo do genoma, desempenho produtivo.

\section{Introduction}

Due to domestication, cultivated rice (Oryza sativa L.) experienced a severe bottleneck effect that has decreased its genetic variability (Tanksley \& McCouch, 1997), resulting in vulnerability to plagues and diseases and decreasing its ability of adapting to adverse field conditions. Furthermore, a limited genetic pool reduces the possibility of additional selection gain in breeding programs (Rangel et al., 1996). Wild relatives of rice comprise an important gene pool that can be used in breeding programs as a source of new genes and alleles of economically important traits, such as resistance to diseases, tolerance to environmental stresses, and yield (Brondani et al., 2002; McCouch et al., 2007; Swamy \& Sarla, 2008; Bimpong et al., 2011).

Variations of the advanced backcross-QTL (AB-QTL) strategy, proposed by Tanksley \& Nelson (1996), have been implemented to assist the introgression of wild chromosome segments in the genetic backgrounds of elite rice cultivars (Rangel et al., 2005; McCouch et al., 2007; Cheema et al., 2008). This strategy allows the identification of alleles related with QTL 
positive effects and the development of introgression lines (IL). These IL can be better described as a set of near-isogenic lines (NIL) developed through a series of backcrosses, containing wild segments in a uniform, cultivated genetic background (Tian et al., 2006; Barone et al., 2009). These lines can be easily maintained by self-pollination and can be very effective in QTL identification and validation because any phenotypic difference between an IL and the recurrent parent can be attributed solely to the donor alleles in the introgressed segment (Lippman et al., 2007).

Oryza rufipogon, a wild relative of rice, has been used in interspecific crosses as a source of alleles to the cultivated rice O. sativa (McCouch et al., 2007). The IL derived from these crosses have been extensively characterized by molecular markers and field-evaluated for yield-related traits (Thomson et al., 2003; Tian et al., 2006; Tan et al., 2007; Cheema et al., 2008). These IL help the understanding of the molecular mechanisms involved in traits of agronomic interest, such as seed size (Li et al., 2004), flowering time (Thomson et al., 2006), and red pericarp (Sweeney et al., 2006). African rice $O$. glaberrima has also been used in wide crosses with $O$. sativa, in an attempt to combine its adaptive characteristics with the favorable agronomic traits from cultivated rice. Rice varieties named New Rice for Africa (Nerica) were developed from interspecific hybrids which were derived from such crosses (Sarla $\&$ Swamy, 2005). Nerica varieties have shown a great ability to compete with weeds, higher tiller number and grain yield similar to that of $O$. sativa (Semagn et al., 2007).

The wild species $O$. glumaepatula Steud. is originated from South and Central America. It belongs to the rice primary gene pool and is completely adapted to Brazilian edaphoclimatic conditions. It grows along riverbeds and margins or as isolated populations, in lowland conditions, far from the rivers (known as marshy valleys), in which case it has a behavior typical of weeds or colonizing plants (Brondani et al., 2001). Oryza glumaepatula has been extensively studied (Vaz et al., 2009), due to its close genetic relationship to cultivated rice and, especially, because it has the potential to successfully transfer favorable yield-related alleles, promoting positive increases in cultivated rice architecture and grain yield (Brondani et al., 2002; Rangel et al., 2005). Oryza glumaepatula has been used as allele donor to elite lines (O. sativa) from the Brazilian rice breeding program since 1996 (Brondani et al., 2001). A set of 35 IL from $O$. sativa BG90-2 x O. glumaepatula RS-16 was developed using a marker-assisted selection to retain favorable wild segments (Rangel et al., 2005, 2008). Under the perspective of introgressing $O$. glumaepatula alleles to other elite rice genotypes, the wild accession RS-16 was used in the present study as the donor parent in a backcross with the high yielding cultivar Cica-8.

The objective of this study was to evaluate the yield performance of two generations $\left(\mathrm{BC}_{2} \mathrm{~F}_{2}\right.$ and $\left.\mathrm{BC}_{2} \mathrm{~F}_{9}\right)$ of introgression lines developed from the interspecific cross between $O$. sativa x $O$. glumaepatula, and to identify SSR markers associated to yield.

\section{Materials and Methods}

The recurrent parent Cica-8 (O. sativa) is an Indica lowland rice cultivar released by Centro Internacional de Agricultura Tropical (CIAT, Colombia) in 1978. Reported yields for this cultivar in Brazil is around $6 \mathrm{Mg} \mathrm{ha}^{-1}$. The cultivar has commercial grain type, medium growth cycle, reduced resistance to leaf blast (Magnaporthe oryzae), and tolerance to aluminium toxicity and drought. The donor parent RS-16 is an O. glumaepatula accession collected in the margins of the Solimões River (Amazon Basin), in Brazil (Rangel et al., 2005).

An interspecific population was developed at Embrapa Arroz e Feijão, in Santo Antônio de Goiás, GO, Brazil, with the initial crosses beginning in 2001. A total of $186 \mathrm{BC}_{1} \mathrm{~F}_{1}$ plants were obtained from the first backcross and were genotyped with 149 molecular markers for the construction of a linkage map (Rangel et al., 2007). From the second backcross, $114 \mathrm{BC}_{2} \mathrm{~F}_{1}$ plants were obtained. These plants were individually self-fertilized without selection until the $\mathrm{F}_{9}$ generation, using the single seed descent (SSD) method, which resulted in $114 \mathrm{BC}_{2} \mathrm{~F}_{9}$ IL.

The first field experiment (experiment A) was conducted to evaluate $114 \mathrm{BC}_{2} \mathrm{~F}_{2}$ families in Goianira, GO, Brazil (749 m, 16 $29^{\prime} 45^{\prime \prime} \mathrm{S}$ and 49 $\left.25^{\prime} 33^{\prime \prime} \mathrm{W}\right)$. A completely randomized block design, with three replicates was used. The plots consisted of three 5-m rows. The recurrent genitor Cica- 8 and the Brazilian cultivar BR IRGA 409 were used as controls. Ten plants per plot were randomly taken to evaluate the following metrics: number of tillers per plant, number 
of panicles per plant, and yield, measured as the total dry grain weight (in grams) per plant.

In the second field trial, $114 \mathrm{BC}_{2} \mathrm{~F}_{9}$ IL were evaluated in three experiments: experiment $\mathrm{B}$, in Alegrete, $\mathrm{RS}$ (102 m, 2947'63"S and 55\%47'54"W,); experiment C, in Goianira, GO; and experiment D, in Boa Vista, RO (85 m, 02 $2^{\circ} 9^{\prime} 17^{\prime \prime} \mathrm{N}$ and $60^{\circ} 39^{\prime} 45^{\prime \prime} \mathrm{W}$ ). The experimental design was a $11 \times 11$ lattice, with three replicates and four 5-m rows per plot. The cultivars Metica 1 and BR IRGA 409 were used as controls, beside the recurrent genitor Cica-8 and the introgression line CNAi 9930, derived from $O$. sativa $\mathrm{BG} 90-2$ × $O$. glumaepatula RS-16 interspecific cross (Rangel et al., 2005). Grain yield was measured as the total dry grain weight (in grams) of ten plants taken at random in each plot.

For the QTL analysis, $114 \mathrm{BC}_{2} \mathrm{~F}_{1}$ plants were genotyped with 141 microsatellite markers distributed along the 12 rice chromosomes. The information related to marker distances were estimated in the $\mathrm{BC}_{1} \mathrm{~F}_{1}$ linkage map (Rangel et al., 2007). Samples of leaf tissue from each $\mathrm{BC}_{2} \mathrm{~F}_{1}$ plant were used for DNA extraction according to Doyle \& Doyle (1987). PCR reactions had a final volume of $15 \mu \mathrm{L}$ containing $15 \mathrm{ng}$ of DNA, $0.3 \mu \mathrm{mol} \mathrm{L}^{-1}$ of each primer, $0.25 \mathrm{mmol} \mathrm{L}^{-1}$ of each dNTP, 5\% (v/v) dimethyl sulfoxide, $10 \mathrm{mmol} \mathrm{L}^{-1}$ of Tris- $\mathrm{HCl}(\mathrm{pH} 8.3), 50 \mathrm{mmol} \mathrm{L}^{-1}$ of $\mathrm{KCl}, 1.5 \mathrm{mmol}^{-1}$ of $\mathrm{MgCl}_{2}$, and one unit of Taq DNA polymerase. Thermocycling was carried out in a GeneAmp PCR System 9700 (Applied Biosystems, Foster City, CA, USA), and the amplification conditions were $94^{\circ} \mathrm{C}$ for $5 \mathrm{~min}$, followed by 40 cycles of $94^{\circ} \mathrm{C}$ for $1 \mathrm{~min}, 56^{\circ} \mathrm{C}$ for $1 \mathrm{~min}$, and $72^{\circ} \mathrm{C}$ for $1 \mathrm{~min}$, and a final extension of $72^{\circ} \mathrm{C}$ for $7 \mathrm{~min}$. The amplification products were separated by electrophoresis on $5 \%(\mathrm{w} / \mathrm{v})$ agarose gel, stained with ethidium bromide $\left(0.1 \mu \mathrm{g} \mu \mathrm{L}^{-1}\right)$ or, when more resolution was needed to detect allele size differences, $6 \%(\mathrm{w} / \mathrm{v})$ denaturing acrylamide gels, stained with silver nitrate, were applied (Creste et al., 2001).

The analysis of variance and statistical comparisons of trait averages were performed using the Genes software (Cruz, 2001). QTL analysis was conducted in the $\mathrm{BC}_{2} \mathrm{~F}_{2}$ population by composite interval mapping (CIM) using the software Windows QTL Cartographer version 2.5 (Wang et al., 2004). The CIM analysis was performed with a window size of $10 \mathrm{cM}$, and the cofactors were determined by a forward-backward stepwise regression (SLE 0.1 and SLS 0.1). Significant thresholds for QTL detection were derived from 1,000 permutations performed for each trait at $5 \%$ probability (Churchill \& Doerge, 1994).

\section{Results and Discussion}

In the experiment $\mathrm{A}, \mathrm{BC}_{2} \mathrm{~F}_{2}$ families did not show superior performance in comparison with the recurrent parent Cica-8 (Table 1). However, some transgressive $\mathrm{BC}_{2} \mathrm{~F}_{2}$ families were observed, with higher number of tillers and panicles than that of cultivated parent Cica-8. Families showing transgressive segregation for the number of tillers and panicles were previously reported in interspecific populations derived from $O$. sativa BG90-2 x O. glumaepatula RS-16 cross (Brondani et al., 2002; Rangel et al., 2005). Panicle number and tiller number are important yield-related traits in rice, since they affect plant architecture, spikelet number, and biomass production (Peng et al., 1999).

Among the $\mathrm{BC}_{2} \mathrm{~F}_{9}$ introgression lines, transgressive segregants were identified for yield in experiments $\mathrm{B}, \mathrm{C}$ and $\mathrm{D}$ (Tables 1 and 2). Overall, nine $\mathrm{BC}_{2} \mathrm{~F}_{9} \mathrm{IL}$ $(5,27,46,60,62,86,88,106$ and 110) showed, in at least one experiment, a significantly higher yield than Cica-8. The IL 5 and 60 showed a significantly increased yield in experiments B and C; the IL 62 and 106, in experiments B and D; and the IL 86, in experiments $\mathrm{C}$ and $\mathrm{D}$ (Table 2). Heterosis possibly have null influence in the yield of transgressive IL in advanced generation $\left(\mathrm{BC}_{2} \mathrm{~F}_{9}\right)$, since the expected rate of heterozygosis is as low as $0.097 \%$. Therefore, these transgressive IL must result from positive allele

Table 1. Total mean and mean ranges of the traits evaluated in $114 \mathrm{BC}_{2} \mathrm{~F}_{2}$ and $\mathrm{BC}_{2} \mathrm{~F}_{9}$ generations for introgression lines (IL) derived from the cross Oryza sativa Cica- $8 \times$ O. glumaepatula RS-16.

\begin{tabular}{|c|c|c|c|c|c|}
\hline Trait & $\begin{array}{l}\text { Experi- } \\
\text { ment }^{(1)}\end{array}$ & Cica-8 & $\begin{array}{c}\mathrm{IL} \\
\text { mean }\end{array}$ & $\begin{array}{c}\mathrm{IL} \\
\text { range }\end{array}$ & $\begin{array}{c}\text { IL transgressive } \\
\text { range }\end{array}$ \\
\hline & \multicolumn{5}{|c|}{$\mathrm{BC}_{2} \mathrm{~F}_{2}$ generations } \\
\hline Tiller number & A & 18.9 & 19.3 & $13.03-31.03$ & $25.6-31.03$ \\
\hline Panicle number & A & 18.9 & 19.1 & $12.08-31.03$ & $25.03-31.03$ \\
\hline \multirow[t]{2}{*}{ Yield $\left(\mathrm{kg} \mathrm{ha}^{-1}\right)$} & A & 6,596 & 2,095 & $1,020-3,674$ & - \\
\hline & \multicolumn{5}{|c|}{$\mathrm{BC}_{2} \mathrm{~F}_{9}$ generations } \\
\hline Yield $\left(\mathrm{kg} \mathrm{ha}^{-1}\right)$ & B & 6,858 & 6,309 & $2,932-9,621$ & $7,728-9,621$ \\
\hline Yield $\left(\mathrm{kg} \mathrm{ha}^{-1}\right)$ & $\mathrm{C}$ & 7,124 & 5,612 & $1,705-8,105$ & $7,454-8,105$ \\
\hline Yield $\left(\mathrm{kg} \mathrm{ha}^{-1}\right)$ & $\mathrm{D}$ & 8,704 & 8,057 & $1,000-10,541$ & $9,193-10,541$ \\
\hline
\end{tabular}


interactions between the wild and cultivated rice. Transgressive segregants were previously reported in interspecific populations using $O$. glumaepatula as the donor parent (Brondani et al., 2002). The same fact was observed when other wild species of Oryza were used as recurrent parents, such as O. rufipogon (McCouch et al., 2007) and O. glaberrima (Bimpong et al., 2011). Since transgressive segregation is the result of allele complementation in each locus and not of heterosis, it can be assumed that transgressive segregants can be maintained in advanced generations, as observed in the present work. According to Rieseberg et al. (1999), the complementary gene action across several loci and allele complementation in one locus are the best explanation for the genetic basis of transgressive segregation. Due to the broad genetic base of interspecific crosses, it is more likely to find new combinations of genes and alleles in them than in crosses between adapted germplasm, such as rice lines and cultivars. In tomato, where interspecific crosses have been extensively explored in the past decades, transgressive segregants were consistently observed in crosses between Solanum lycopersicum and $S$. pennellii, and were described as a result of novel interactions between alleles from both species (Lippman et al., 2007).

The 141 microsatellite markers used to genotype $\mathrm{BC}_{2} \mathrm{~F}_{1}$ plants were distributed along the 12 rice chromosomes, covering $1,576.9 \mathrm{cM}$ of the genome, with an average marker distance of $12.5 \mathrm{cM}$, similar to the 1,500.4 cM covered length and the $10 \mathrm{cM}$ distance previously described in O. sativa BG 90-2

Table 2. Yield averages $\left(\mathrm{kg} \mathrm{ha}^{-1}\right)$ of nine highyielding introgression lines at $\mathrm{BC}_{2} \mathrm{~F}_{2}$ and $\mathrm{BC}_{2} \mathrm{~F}_{9}$ generations ${ }^{(1)}$.

\begin{tabular}{lccccc}
\hline Introgression & $\mathrm{BC}_{2} \mathrm{~F}_{2}$ & & \multicolumn{3}{c}{$\mathrm{BC}_{2} \mathrm{~F}_{9}$} \\
\cline { 2 - 3 } \cline { 5 - 6 } line & Goianira $(\mathrm{A})$ & & Alegrete $(\mathrm{B})$ & Goianira $(\mathrm{C})$ & Boa Vista (D) \\
\hline 5 & $4,052 \mathrm{c}$ & & $7,645 \mathrm{a}$ & $7,869 \mathrm{a}$ & $8,439 \mathrm{~b}$ \\
27 & $5,916 \mathrm{a}$ & & $8,133 \mathrm{a}$ & $6,249 \mathrm{c}$ & $8,132 \mathrm{c}$ \\
46 & $6,402 \mathrm{a}$ & & $7,728 \mathrm{a}$ & $6,211 \mathrm{c}$ & $8,444 \mathrm{~b}$ \\
60 & $4,044 \mathrm{c}$ & & $9,427 \mathrm{a}$ & $8,105 \mathrm{a}$ & $8,622 \mathrm{~b}$ \\
62 & $6,330 \mathrm{a}$ & & $7,391 \mathrm{a}$ & $6,161 \mathrm{c}$ & $9,883 \mathrm{a}$ \\
86 & $4,036 \mathrm{c}$ & & $5,645 \mathrm{c}$ & $7,728 \mathrm{a}$ & $9,311 \mathrm{a}$ \\
88 & $6,352 \mathrm{a}$ & & $8,635 \mathrm{a}$ & $6,211 \mathrm{c}$ & $7,745 \mathrm{c}$ \\
106 & $3,614 \mathrm{c}$ & & $9,621 \mathrm{a}$ & $6,088 \mathrm{c}$ & $9,749 \mathrm{a}$ \\
110 & $6,340 \mathrm{a}$ & & $5,050 \mathrm{c}$ & $6,458 \mathrm{c}$ & $10,541 \mathrm{a}$ \\
\hline Cica-8 & $6,596 \mathrm{a}$ & $6,858 \mathrm{~b}$ & $7,124 \mathrm{~b}$ & $8,704 \mathrm{~b}$ \\
\hline
\end{tabular}

${ }^{(1)}$ Means followed by equal letters do not differ by Scott-Knott test, at $5 \%$ probability. x O. glumaepatula RS-16 map (Brondani et al., 2001). The number of introgressed heterozygous segments containing wild alleles ranged from 3 (plant 112) to 23 (plant 68), with an average of 10 segments per plant. Proportions of wild fragment introgressions ranged from 5.6 (plant 46) to $49.7 \%$ (plant 95), with an average of $22.1 \%$, which did not deviate $(\mathrm{p}<0.01)$ from the expected heterozygous proportion of $25 \%$ in an unselected $\mathrm{BC}_{2}$ population.

The CIM analysis conducted in the $\mathrm{BC}_{2} \mathrm{~F}_{2}$ families (experiment A) allowed the detection of seven marker intervals associated with the evaluated traits (Table 3 and Figure 1). The tiller number and panicle number, which are highly correlated traits (Peng et al., 1999), showed QTL detected at the same marker intervals on chromosomes 7 (4752-RM82) and 11 (5335-RM20), with favorable allele coming from the wild parent $O$. glumaepatula, in the first interval, and from the cultivated parent in the second interval. The co-localization of the QTL found for panicle number and tiller number, in the $\mathrm{BC}_{2} \mathrm{~F}_{2}$ families, corroborates previous findings showing that $O$. glumaepatula alleles acted on increasing the performance of these traits (Brondani et al., 2002; Rangel et al., 2005). The QTL located along the marker intervals 4879-EST20 and 4599-RM202 was associated with yield. The 4879-EST20 explained the higher proportion $\left(\mathrm{R}^{2}=21.29\right)$ of the phenotypic variation, indicating a target genome region for the search of genes of great effect in rice (Table 3 ). This region spans for a $40 \mathrm{cM}$ in the linkage map (Figure 1), and corresponds to $4 \mathrm{Mbp}$ in the rice structural genome (Rice Genome Annotation Project, 2013). The running of the annotation algorithm for monocots, in the same website, made

Table 3. Markers at QTL, detected by composite interval mapping at generation $\mathrm{BC}_{2} \mathrm{~F}_{2}$ on experiment $\mathrm{A}$, in Goianira, GO.

\begin{tabular}{lccccc}
\hline Trait & \multicolumn{5}{c}{ Composite interval mapping } \\
\cline { 2 - 6 } & Chromosome & Marker interval & LOD score & \\
\hline Tiller & 7 & 4752RM82 & 4.2 & 3.02 & 11.01 \\
number & 11 & 5335RM20 & 3.7 & 2.21 & 9.68 \\
Panicle & 7 & 4752RM82 & 4.2 & 2.92 & 10.97 \\
number & 11 & 5335RM20 & 3.3 & 2.01 & 8.53 \\
Yield & 4 & 4879EST20 & 6.2 & 3.34 & 21.29 \\
$\left(\mathrm{~kg} \mathrm{ha}^{1}\right)$ & 11 & 4599RM202 & 4.1 & 8.58 & 13.38 \\
\hline
\end{tabular}

${ }^{(1)}$ Minimum threshold for QTL detection determined by 1,000 permutations. ${ }^{(2)}$ Increase in numerical representation of trait values; negative effect indicates allele contribution from the wild parental. ${ }^{(3)}$ Proportion of phenotypic variation explained by each QTL; minimum threshold at $1 \%$ probability. 

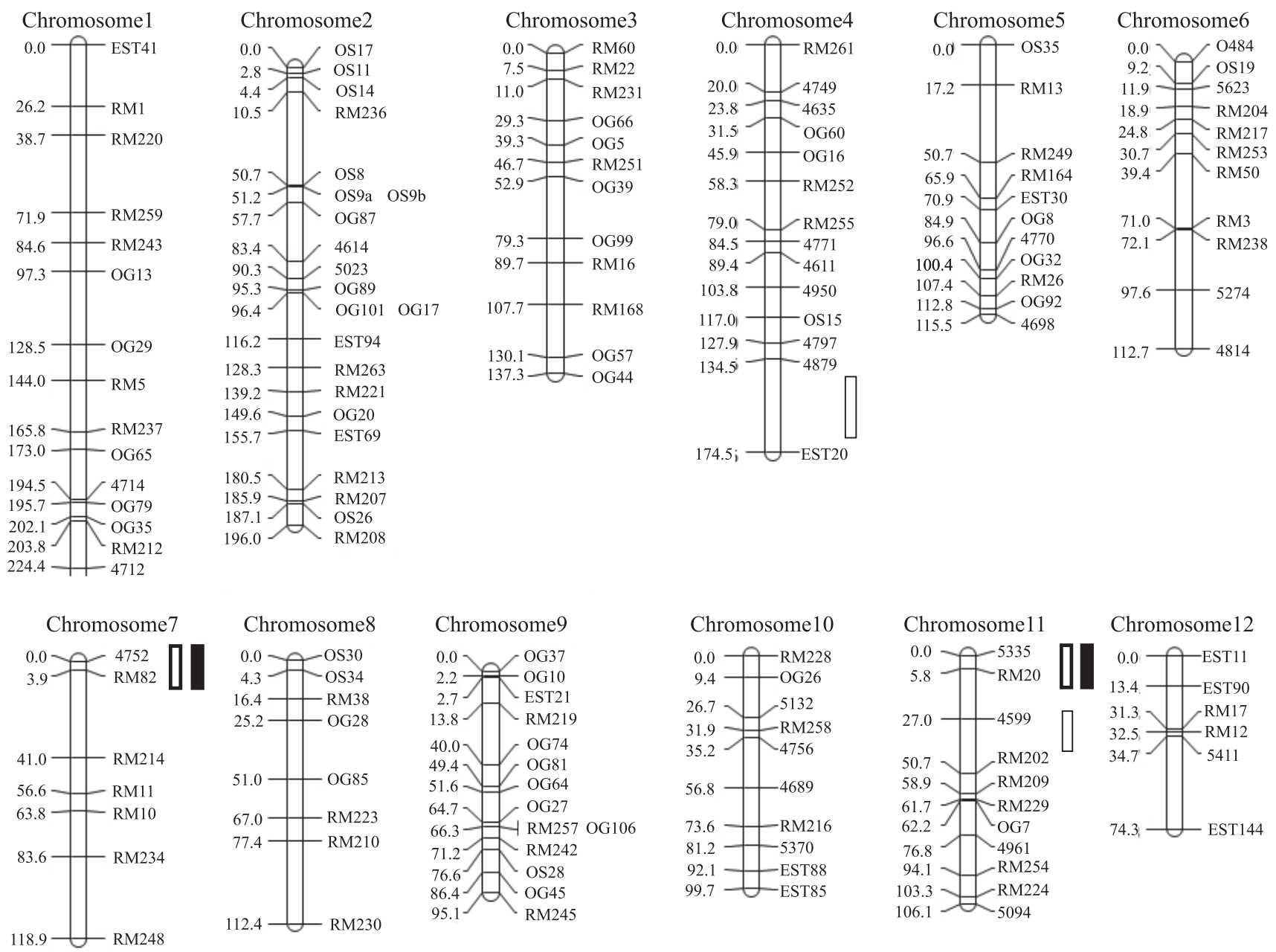

Figure 1. Genetic linkage map obtained from a $\mathrm{BC}_{2} \mathrm{~F}_{2}$ population derived from the cross Oryza sativa Cica- 8 × O. glumaepatula RS-16. The squares indicate the locations of QTL detected for tiller number (unfilled bold square), panicle number (filled square) and yield (unfilled thin square).

it possible to identify 596 putative genes or one gene every 6,700 base pairs. To identify genes or group of genes positively related to the yield increase in this 4879-EST20 marker interval, it will be necessary to perform a QTL fine mapping to reduce the number of potential genes to be analyzed in detail by functional genomics, site-directed mutagenesis, interference RNA, gene cloning and gene over-expression.

\section{Conclusions}

1. Interspecific crosses between Oryza glumaepatula and $O$. sativa are able to generate inbred lines with higher yield performance than the cultivated genitor.

2. Alleles with positive effect on yield came from the cultivated parent Cica-8.
3. There are seven marker intervals associated with yield and with tiller and panicle number in $\mathrm{BC}_{2} \mathrm{~F}_{2}$ families derived from the cross $O$. sativa Cica- 8 x O. glumaepatula RS-16; QTL located along the marker interval 4879-EST20 and 4599-RM202 are associated with yield, and the 4879-EST20 marker interval explains the higher proportion of phenotypic variation, indicating a target genome region for the search of genes of great effect in rice.

\section{References}

BARONE, A.; DI MATTEO, A.; CARPUTO, D.; FRUSCIANTE, L. High-throughput genomics enhances tomato breeding efficiency. Current Genomics, v.10, p.1-9, 2009. DOI: 10.2174/138920209787581226. 
BIMPONG, I.K.; SERRAJ, R.; CHIN, J.H.; RAMOS, J.; MENDOZA, E.M.T.; HERNANDEZ, J.E.; MENDIORO, M.S.; BRAR, D.S. Identification of QTLs for drought-related traits in alien introgression lines derived from crosses of rice Oryza sativa cv. IR64 x O. glaberrima under lowland moisture stress. Journal of Plant Biology, v.54, p.237-250, 2011. DOI: 10.1007/ s12374-011-9161-z.

BRONDANI, C.; BRONDANI, R.P.V.; RANGEL, P.H.N.; FERREIRA, M.E. Development and mapping of Oryza glumaepatula-derived microsatellite markers in the interspecific cross Oryza glumaepatula x O. sativa. Hereditas, v.114, p.59-71, 2001. DOI: 10.1111/j.1601-5223.2001.00059.x.

BRONDANI, C.; RANGEL, P.H.N.; BRONDANI, R.P.V.; FERREIRA, M.E. QTL mapping and introgression of yield related traits from Oryza glumaepatula to cultivated rice (Oryza sativa) using microsatellite markers. Theoretical and Applied Genetics, v.104, p.1192-1203, 2002. DOI: 10.1007/s00122-002-0869-5.

CHEEMA, K.K.; BAINS, N.S.; MANGAT, G.S.; DAS, A.; VIKAL, Y.; BRAR, D.S.; KUSH, G.S.; SINGH, K. Development of high yielding IR64 $\times$ Oryza rufipogon (Griff.) introgression lines and identification of introgressed alien chromosome segments using SSR markers. Euphytica, v.160, p.401-409, 2008. DOI: 10.1007/ s10681-007-9560-x.

CHURCHILL, G.A.; DOERGE, R.W. Empirical threshold values for quantitative trait mapping. Genetics, v.138, p.963-971, 1994.

CRESTE, S.; TULMANN NETO, A.; FIGUEIRA, A. Detection of single sequence repeat polymorphisms in denaturing polyacrylamide sequencing gels by silver staining. Plant Molecular Biology Reporter, v.19, p.299-306, 2001. DOI: 10.1007/BF02772828.

CRUZ, C.D. Programa Genes: aplicativo computacional em genética e estatística. Versão Windows. Viçosa: UFV, 2001. 648p.

DOYLE, J.J.; DOYLE, J.L. Isolation of plant DNA from fresh tissue. Focus, v.12, p.13-15, 1987.

LI, J.; THOMSON, M.; MCCOUCH, S.R. Fine mapping of a grain weight Quantitative Trait Locus in the pericentromeric region of rice chromosome 3. Genetics, v.168, p.2187-2195, 2004. DOI: 10.1534/genetics.104.034165.

LIPPMAN, Z.B.; SEMEL, Y.; ZAMIR, D. An integrated view of quantitative trait variation using tomato interspecific introgression lines. Current Opinion in Genetics and Development, v.17, p.545-552, 2007. DOI: 10.1016/j.gde.2007.07.007.

MCCOUCH, S.R.; SWEENEY, M.; LI, J.; JIANG, H.; THOMSON, M.; SEPTININGSIH, E.; EDWARDS, J.; MONCADA, P.; XIAO, J.; GARRIS, A.; TAI, T.; MARTINEZ, C.; TOHME, J.; SUGIONO, M.; MCCLUNG, A.; YUAN, L.P.; AHN, S.-N. Through the genetic bottleneck: $O$. rufipogon as a source of trait-enhancing alleles for O. sativa. Euphytica, v.154, p.317-339, 2007. DOI: 10.1007/ s10681-006-9210-8.

PENG, S.; CASSMAN, K.G.; VIRMANI, S.S.; SHEEHY, J.; KUSH, G.S. Yield potential trends of tropical rice since the release of IR8 and the challenge of increasing rice yield potential. Crop Science, v.39, p.1552-1559, 1999. DOI: 10.2135/ cropsci1999.3961552x.
RANGEL, P.H.N.; BRONDANI, C.; RANGEL, P.N.; BRONDANI, R.P.V.; ZIMMERMANN, F.J.P. Development of rice lines with gene introgression from the wild Oryza glumaepatula by the AB-QTL methodology. Crop Breeding and Applied Biotechnology, v.5, p.10-19, 2005.

RANGEL, P.H.N.; GUIMARÃES, E.P.; NEVES, P.C.F. Base genética das cultivares de arroz (Oryza sativa L.) irrigado do Brasil. Pesquisa Agropecuária Brasileira, v.31, p.349-357, 1996.

RANGEL, P.N.; BRONDANI, R.P.V.; COELHO, A.S.G.; RANGEL, P.H.N.; BRONDANI, C. Comparative linkage mapping of Oryza glumaepatula and Oryza sativa interspecific crosses based on microsatellite and expressed sequence tag markers. Genetics and Molecular Biology, v.30, p.614-622, 2007. DOI: 10.1590/ S1415-47572007000400019.

RANGEL P.N.; BRONDANI, R.P.V.; RANGEL, P.H.N.; BRONDANI, C. Agronomic and molecular characterization of introgression lines from the interspecific cross Oryza sativa BG90-2 X Oryza glumaepatula RS-16. Genetics and Molecular Research, v.7, p.184-195, 2008. DOI: 10.4238/vol7-1gmr406.

RICE GENOME ANNOTATION PROJECT. Rice Genome Annotation Project. 2013. Available at: $<$ http://rice.plantbiology. msu.edu/home_contacts.shtml >. Accessed on: 15 Apr. 2013.

RIESEBERG, L.H.; ARCHER, M.A.; WAYNE, R.K. Transgressive segregation, adaptation and speciation. Heredity, v.83, p.363-372, 1999. DOI: 10.1038/sj.hdy.6886170.

SARLA, N.; SWAMY, B.P.M. Oryza glaberrima: a source for the improvement of Oryza sativa. Current Science, v.89, p.955-963, 2005.

SEMAGN, K.; NDJIONDJOP, M.N.; LORIEUX, M.; CISSOKO, M.; JONES, M.; MCCOUCH, S. Molecular profiling of an interspecific rice population derived from a cross between WAB 56-104 (Oryza sativa) and CG 14 (Oryza glaberrima). African Journal of Biotechnology, v.6, p.2014-2022, 2007.

SWAMY, B.P.M.; SARLA, N. Yield-enhancing quantitative trait loci (QTLs) from wild species. Biotechnology Advances, v.26, p.106-120, 2008. DOI: 10.1016/j.biotechadv.2007.09.005.

SWEENEY, M.; THOMSOM, M.J.; PFEIJ, B.; MCCOUCH, B. Caught red-handed: Rc encodes a basic helix-loop-helix protein conditioning red pericarp in rice. Plant Cell, v.18, p.283-294, 2006. DOI: $10.1105 /$ tpc. 105.038430 .

TAN, L.; LIU, F.; XUE, W.; WANG, G.; YE, S.; ZHU, Z.; FU, Y.; WANG, X.; SUN, C. Development of Oryza rufipogon and $O$. sativa introgression lines and assessment for yield-related quantitative trait loci. Journal of Integrative Plant Biology, v.49, p.871-884, 2007. DOI: 10.1111/j.1744-7909.2007.00497.x.

TANKSLEY, S.D.; MCCOUCH, S.R. Seed banks and molecular maps: unlocking genetic potential from the wild. Science, v.277, p.1063-1066, 1997. DOI: 10.1126/science.277.5329.1063.

TANKSLEY, S.D.; NELSON, J.C. Advanced backcross QTL analysis: a method for the simultaneous discovery and transfer of valuable QTLs from unadapted germplasm into elite breeding lines. Theoretical and Applied Genetics, v.92, p.191-203, 1996. DOI: $10.1007 / \mathrm{s} 001220050114$. 
THOMSON, M.J.; EDWARDS, J.D.; SEPTININGSIH, E.M.; HARRINGTON, S.; MCCOUCH, S.R. Substitution mapping of $d t h 1.1$, a flowering time Quantitative Trait Locus (QTL) associated with transgressive variation in rice, reveals multiple sub-QTL. Genetics, v.172, p.2501-2514, 2006. DOI: 10.1534/ genetics.105.050500.

THOMSON, M.J.; TAI, T.H.; MCCLUNG, A.M.; LAI, X.H.; HINGA, M.E.; LOBOS, K.B.; XU, Y.; MARTINEZ, C.P.; MCCOUCH, S.R. Mapping quantitative trait loci for yield, yield components and morphological traits in an advanced backcross population between Oryza rufipogon and the Oryza sativa cultivar Jefferson. Theoretical and Applied Genetics, v.107, p.479-493, 2003. DOI: $10.1007 / \mathrm{s} 00122-003-1270-8$.

TIAN, F.; LI, D.J.; FU, Q.; ZHU, Z.F.; FU, Y.C.; WANG, X.K.; SUN, C.Q. Construction of introgression lines carrying wild rice (Oryza rufipogon Griff.) segments in cultivated rice (Oryza sativa L.) background and characterization of introgressed segments associated with yield-related traits. Theoretical and Applied Genetics, v.112, p.570-580, 2006. DOI: 10.1007/s00122-005-0165-2.

VAZ, A.R. de C.; BORBA, T.C. de O.; BRONDANI, C.; RANGEL, P.H.N.; CAMARGO, G.S. de O.; TELLES M.P. de C.; DINIZ FILHO, J.A.F.; BRONDANI, R.P.V. Genetic analysis of a local population of Oryza glumaepatula using SSR markers: implications for management and conservation programs. Genetica, v.137, p.221-231, 2009. DOI: 10.1007/s10709-009-9393-8.

WANG, S.; BASTEN, C.J.; ZENG, Z.-B. Windows QTL Cartographer. Version 2.0. Raleigh: Department of Statistics, North Carolina State University, 2004. Available at: <http:// statgen.ncsu.edu/qtlcart/WQTLCart.htm>. Accessed on: 20 Feb. 2012.

$\overline{\text { Received on October 1ㅇ, } 2012 \text { and accepted on February 19, } 2013}$ 